\title{
Reduzindo as incertezas em relação aos bancos estrangeiros
}

\begin{abstract}
Resumo
A liberalização financeira que ocorreu nas décadas de 1970 e 1980 permitiu um maior influxo de bancos estrangeiros para países outrora com restrições a esse tipo de capital, entretanto, foi somente nos anos 90 que os países em desenvolvimento experimentaram uma maciça entrada dessas instituições em seus territórios. Com o passar dos anos vários estudos analisaram os efeitos desses bancos na economia doméstica, e embora tenham reduzido o grau de incerteza em relação a algumas consequências decorrentes dessa incursão, restam questões para serem debatidas. Esse artigo é um survey que reflete sobre essas questões, concluindo que maior transparência, regulação e entendimento das características da economia receptora e do banco entrante são fatores cruciais para o país doméstico conseguir receber os benefícios que podem advir desse tipo de influxo.
\end{abstract}

Palavras-chave: Bancos; Crédito; Crises Financeiras.

\begin{abstract}
The financial liberalization that occurred in the 1970s and 1980s allowed a greater inflow of foreign banks to once countries with restrictions on this type of capital, however, was only in the 90s that developing countries experienced a massive entrance of these institutions in their territories. Over the years several studies examined the effects of these banks in the domestic economy, and although they have reduced the degree of uncertainty about some consequences of this incursion, remain issues to be discussed. This article is a survey that reflects on these issues, concluding that greater transparency, regulation and understanding of the characteristics of the receiving economy and incoming bank are crucial factors for the home country be able to receive the benefits that may result from this type of influx.
\end{abstract}

Keywords: Banks; Credit; Financial Crises.

JEL: G21, E02, G01. 


\section{INTRODUÇÃO}

A liberalização financeira que ocorreu nas décadas de 1970 e 1980 representou a redução do papel do governo na economia local, o aumento dos fluxos de capitais e maior integração econômica mundial. Os capitais passaram a serem vistos desprovidos de pátria, buscando oportunidades de lucros em mercados recentemente abertos a influxos estrangeiros, pouco se importando com a nacionalidade desse novo mercado.

Conquanto a liberalização financeira tenha ocorrido décadas anteriores, foi somente nos anos 90 que o fluxo de bancos estrangeiros ganhou importância nos países em desenvolvimento, adentrando em seus mercados e, em muitos casos, passando a deterem a maior parte dos ativos bancários, isto é, se tornaram os principais agentes do sistema bancário local.

Fatores como custos de reestruturação dos bancos domésticos após crises econômicas, ensejo de incrementar a robustez do sistema bancário, aumentar a eficiência da economia e a influência de órgãos proeminentes globalmente como o Fundo Monetário Internacional (FMI) e a Organização para Cooperação e Desenvolvimento Econômico (OCDE), bem como o Consenso de Washington, ajudam a entender esse forte influxo de bancos estrangeiros nos anos 90. Ademais, oportunidades de lucratividade nos países em desenvolvimento foi outro fator que propiciou essa guinada de bancos estrangeiros para essas nações.

Entretanto, ainda que a entrada dos bancos estrangeiros tenha sido defendida, existiam muitas dúvidas quanto aos efeitos causados por estes nos países receptores. Deste modo, além de argumentos nacionalistas e de indústria nascente, a incerteza dos possíveis benefícios e custos advindos da incursão desses bancos era outro fator a prejudicar esse tipo de influxo de investimento direto estrangeiro (IDE). Todavia, com inúmeros estudos tendo sido realizados, juntamente com a análise retrospectiva de países que reduziram suas restrições e aceitaram a entrada desses bancos, se tornou mais claro o papel desses bancos nos mercados domésticos.

Com o avanço da literatura sobre bancos estrangeiros desde os anos 90, esse artigo procura precisar o debate sobre algumas consequências da entrada desses bancos, bem como consensos e divergências na literatura, não deixando de fazer uma análise crítica sobre cada tema. Não obstante algumas controvérsias tenham sido resolvidas, outras ainda permanecem e mais estudos são necessários para mitigar essas dúvidas, entretanto, conforme será mostrado ao longo do trabalho, a entrada de bancos estrangeiros tem se mostrado favorável ao crescimento e desenvolvimento econômico e social de muitas nações, ainda que existam casos que desmintam essa relação, como é elucidado posteriormente. 
Para esse intuito o artigo está divido em 3 seções, além dessa breve introdução. A próxima seção trata da tendência dos bancos estrangeiros de se espalharem em volta do globo; a terceira seção tece análises sobre várias consequências da entrada dessas instituições, focalizando nos países em desenvolvimento; por fim, a seção 4 faz algumas considerações finais.

\section{ENTRADA DOS BANCOS ESTRANGEIROS}

O sistema financeiro mundial fora regido pelo regime de repressão financeira desde o final da segunda guerra mundial até os anos de 1970. Esse regime colapsou devido à situação econômica instável de várias economias nessa época, que apresentavam alta inflação e baixo crescimento econômico.

O regime de repressão financeira pode ser entendido pelo controle do Estado sobre o sistema financeiro nacional, coordenando algumas variáveis e restringindo a liberdade de atuação das instituições financeiras circunscritas a ele, entre elas, os bancos. Em especial, o fluxo de capital era restrito, sendo que somente determinado tipo de capital poderia entrar, sob o aval do governo.

O funcionamento do sistema bancário foi considerado um dos responsáveis pelo baixo dinamismo da atividade econômica nos anos de 1970 e, portanto, foi alvo de inúmeras críticas neoliberais. $\mathrm{Na}$ essência dessas críticas, pode-se resumi-las na defesa pela retirada do governo da órbita da economia e o desejo de que as forças de mercado voltassem a coordenar o funcionamento econômico (Mishkin, 2009; Williamson e Mahar, 1998). Para os propósitos desse trabalho, em relação ao setor bancário argumentou-se pela retirada das barreiras que impediam a entrada dos bancos estrangeiros.

Embora a liberalização financeira tenha se iniciado nos anos 70, somente nos anos de 1990 que a entrada dos bancos estrangeiros nos países em desenvolvimento ganhou ímpeto. De 1994 a 1999 os ativos bancários mantidos por bancos estrangeiros subiram de 20\% para mais de 50\% em países como a Argentina, Chile, República Tcheca, Hungria e Polônia (Clarke et al, 2003). Além de elucidar esse salto na participação dos bancos estrangeiros em outros países, esses números mostram que essa incursão foi desigual no espaço, em particular, ela foi concentrada na América Latina (Argentina e Chile) e Europa Oriental (República Tcheca, Hungria e Polônia).

Aumentando o escopo do período dos dados, de 1995 a 2009 a participação dos bancos estrangeiros nos países emergentes passou de 18\% em 1995 para 36\% em 2009, nos países em 
desenvolvimento que era de $24 \%$ subiu para $45 \%$, na Europa Oriental e Ásia Central se elevou de $15 \%$ para $47 \%$, de $28 \%$ para $42 \%$ na América Latina e Caribe, de $7 \%$ para $13 \%$ no sul da Ásia e de 31\% para 53\% na África Subsaariana (Claessens e Van Horen, 2014). Os bancos estrangeiros aumentaram a sua participação mundial e passaram a exercer um importante papel em vários países, entretanto, em algumas regiões, como o sul da Ásia, ainda é nítido a baixa penetração dessas instituições.

Destarte, essa onda de bancos estrangeiros pode representar a busca de países para fortalecerem suas economias, principalmente no tocante ao sistema financeiro e bancário. Essa cooperação é importante para superar vicissitudes que eventualmente surgem no cenário mundial. E quem sabe a cooperação entre países pode atingir o sistema bancário doméstico, formando alianças entre bancos estrangeiros e locais, o que consubstanciaria uma integração regional. Como será visto mais adiante, algumas alianças já existem, o que pode ser um prelúdio para essa maior integração no sistema bancário.

\section{ANÁLISE DA INCURSÃO DE BANCOS ESTRANGEIROS}

O objetivo dessa seção é precisar sobre os possíveis efeitos da entrada de bancos estrangeiros, efeitos estes principalmente sobre os países em desenvolvimento. Como ficará claro ao longo do debate, muitas incertezas pairam a respeito desse tipo de influxo de investimento direto estrangeiro (IDE). Entretanto, desde que esse fluxo de instituições bancárias se iniciou - nos anos de 1970, porém, ganhando maior ímpeto nos anos de 1990 - muitos estudos foram realizados, o que amenizou o grau de dúvidas quanto aos seus efeitos na economia.

\subsection{Concentração Bancária e Controle Externo}

Há o risco dos formuladores de política econômica do país doméstico perderem poder para influenciar no funcionamento do sistema bancário. Se com bancos públicos o governo possuía margem para aumentar ou reduzir o volume de créditos, direcionamento do crédito para determinado setor, redução da taxa de juros e outras manobras, a aglomeração de bancos estrangeiros tende a extirpar essa intervenção pública. Por outro lado, regulamentações podem mitigar esse efeito.

O risco de transmissão de choques do país em que o banco matriz está localizado é incrementado. Caso o banco matriz sofra perdas econômicas e necessite de ajustar o seu balanço, mesmo que suas filiais estejam com bom funcionamento financeiro e gerando receitas, o risco de encerrar suas atividades não é nulo. De forma análoga, os empréstimos de suas 
subsidiárias e filiais podem ser arrefecidos como medida para superar o atual momento adverso, novamente, gerando consequências recessivas para o país que as hospeda.

Uma estrutura bancária caracterizada por oligopólios e monopólios estrangeiros poderia emergir. Os possíveis problemas que poderiam advir desse quadro são semelhantes com os traços criticados pelos neoliberais em relação à estrutura bancária concentrada de países sob o regime de repressão financeira, isto é, oligopólios e monopólios públicos (Fry, 1988; Mckinnon, 1973; Shaw, 1973). Reduzida transparência, taxas de juros altas, spreads bancários elevados e irrisória concorrência seriam traços perniciosos para o funcionamento do sistema bancário, entretanto, deve-se ter cautela para tomar conclusões, dado que essa estrutura concentrada pode ser capaz de acarretar adequada provisão de serviços financeiros. Para cada país, a maneira com a qual o sistema financeiro se encaixa e operacionaliza é bastante peculiar, podendo existir países com estruturas concentradas de bancos de propriedade estrangeira e com sistema financeiro funcionando adequadamente e o oposto, estruturas pouco concentradas e com o sistema financeiro pouco desenvolvido - e essa é uma das principais mensagens desse artigo em relação ao impacto dos bancos estrangeiros, as características econômicas, culturais e políticas de cada nação não podem ser negligenciadas para mensurar os efeitos da entrada de bancos em seus territórios, bem como a maneira em que irão operar.

Grahan (2004) explana que sistemas bancários concentrados podem se deparar com "gentlemen's rules". Nesse tipo de estrutura, bancos apoiariam o surgimento de firmas aceitando prejuízos em sua fase inicial, sabendo que anos mais tarde recuperariam o capital perdido com os ganhos provenientes de empréstimos com juros elevados por essas mesmas firmas. Um mesmo banco apoiaria o amadurecimento da firma e os outros não tentariam tomar o seu cliente, ou seja, não haveria o comportamento de free-rider. Por outro lado, em uma estrutura pouco concentrada é pouco verossímil que bancos aceitariam incorrerem em prejuízos no início do crescimento da empresa, pois quando essa estivesse apta a gerar receitas, ela poderia escolher bancos que oferecessem melhores empréstimos. Uma maneira de contornar esse problema seria o banco possuir posições de capital na empresa.

Por fim, Levine (2000) afirma que concentrações bancárias não prejudicam o crescimento do produto interno bruto (PIB), enquanto Cetorelli e Gambera (2001) asseveram o contrário, o PIB se reduziria. O denominador comum desse embate é, como mencionado anteriormente, considerar as instituições de cada país para empreender a estrutura bancária almejada e obter os resultados desejados. 


\subsection{Choques Externos}

O principal argumento era de que a entrada de bancos estrangeiros aumentaria a estabilidade financeira do país (Clarke et al, 2003; Detragiache e Gupta, 2006; Goldberg, 2009). Todavia, essa entrada poderia aumentar ou reduzir a transmissão de choques externos (Clarke et al, 2003; Goldberg, 2009).

A estabilidade poderia ser recrudescida com a manutenção ou incremento do empréstimo feito por bancos estrangeiros em momentos de crise econômica no país doméstico. Conforme o nível da atividade produtiva se reduzisse, o nível de investimento e consumo poderiam ser sustentados por esses empréstimos, fazendo com que a demanda agregada não sofresse uma forte queda. Clarke et al (2003) realça que esses empréstimos não declinaram na crise asiática de 1997 e, por conseguinte, agiram como fatores estabilizadores. Por outro lado, Mathieson e Roldós (2004) denotam que nessa mesma crise as matrizes não auxiliaram suas subsidiárias e filiais, o que jogou um papel desfavorável para a estabilidade.

Conquanto esse tema ainda não tenha atingido um consenso, alguns fatores ajudam a entender como a entrada de bancos estrangeiros aumentaria a estabilidade financeira. Esses bancos possuem maior acesso a fundos externos, podendo utilizar dessa fonte de capital para aumentarem a liquidez da economia doméstica quando períodos recessivos se aproximassem, ao contrário dos bancos domésticos que primordialmente contam somente com fundos internos de capital. Dessa maneira, mesmo que fugas de capitais se desencadeassem no país, os bancos estrangeiros disporiam de fundos para efetuarem suas atividades e evitar uma queda abrupta no financiamento.

Alguns países da América Latina possuem o setor bancário com bancos estrangeiros de um único país, como é o caso do Banco Santander, advindo da Espanha (Grahan, 2004). O risco dessa situação é que caso a Espanha esteja passando por alguma vicissitude econômica o choque poderia facilmente se propagar para o país que hospeda esse banco, e na ausência de diversidade de bancos estrangeiros, mecanismos que favoreceriam a estabilização financeira estariam ausentes. O ideal é o país possuir uma variedade de bancos estrangeiros provenientes de variados países, de modo que o risco de transmissão dos choques seja reduzido.

A desvalorização do real em janeiro de 1999 e a subsequente crise que o Brasil enfrentou e o efeito contágio da crise russa de 1998 na Hungria são exemplos de subsidiárias e filiais estrangeiras que receberam fundos de suas matrizes para superarem o momento adverso, entretanto, essa não é a regra, como bem ilustrado pela crise asiática em 1997 (Mathieson e Roldós, 2004). Todavia, fatores como maior diversidade da origem dos bancos estrangeiros e 
acesso a fundos externos são peças que ajudam a tornar a estabilidade financeira mais robusta e reduzir a eclosão de crises financeiras.

\subsection{Competição Bancária}

Com a entrada dos bancos estrangeiros acreditava-se que os custos operacionais dos bancos domésticos seriam reduzidos na medida em que estes teriam de se tornarem mais competitivos para poderem sobreviver no mercado bancário, agora mais estreito e com potenciais concorrentes. As elevadas margens de lucros e ganhos advindos pelas também altas taxas de juros observadas no sistema bancário doméstico foram considerados como sinais de ineficiência nesse setor e a entrada dos bancos era esperada para ajustar o mercado bancário.

Os novos produtos e serviços financeiros que corriqueiramente são introduzidos após a entrada dos bancos atingem partes do mercado antes não cobertas por esses serviços. A vantagem dessa penetração bancária é que às vezes ela não representa de fato uma concorrência com o setor doméstico, apenas aumenta o escopo do mercado bancário. Além disso, os bancos domésticos ganham mais tempo para se ajustarem e melhorarem o seu funcionamento para competirem com os novos bancos. Classes de renda outrora excluídas do sistema financeiro agora se veem na possibilidade de participarem desse mercado e possivelmente incrementarem os seus consumos ou padrões de vida. Essa incorporação de novas pessoas no sistema financeiro ilustra o fenômeno que tem ocorrido desde os anos de 1970, que é a crescente financeirização das economias (Lapavitsas, 2009; Lapavitsas, 2011).

As técnicas de funcionamento desses bancos, como os modelos de avaliação do risco do crédito, podem ser absorvidas pelas instituições domésticas. Esse argumento é costumeiramente utilizado para a entrada de investimento direto estrangeiro, principalmente na forma de greenfield, que é o investimento na construção da instituição no país destinatário, não o IDE na forma de fusão e aquisição. Entretanto, alguns autores rechaçam esse argumento, como é o caso de Goldberg (2009), que afirma que a transferência de tecnologia posteriormente à entrada de bancos estrangeiros é limitada, portanto, o aumento da eficiência ocorreria por outros canais.

Fatores institucionais e culturais do país receptor são importantes para avaliar a efetividade da entrada dos bancos estrangeiros na concorrência doméstica (Claessens e Van Horen, 2013). Aparatos regulatórios, linguagem e modo de relacionamento dos agentes com as instituições bancárias são elementos que influem no desempenho do banco estrangeiro e, portanto, no mercado bancário doméstico. Como será explanado mais adiante, bancos que consideram esses fatores antes de adentrarem nos mercados auferem melhor performance. 
Para finalizar, nem todos os bancos estrangeiros são mais eficientes que os bancos domésticos, todavia, por vezes a entrada daqueles altera o modo de funcionamento do mercado bancário doméstico. Bancos domésticos que se preocupavam pouco com a concorrência, em manter clientes, produzir novos produtos e serviços, são retirados dessa inércia e passam a tomar medidas para manterem a parte do mercado e quem sabe até aumentá-la (Grahan, 2004).

\subsection{Desempenho dos Bancos Estrangeiros em Diferentes Nações}

Estudos como os de Berger et al (2000), De Young e Nolle (1996) e Chang et al (1998) denotam que bancos estrangeiros são menos eficientes que os bancos domésticos nos países desenvolvidos, por outro lado, Kiraly et al (2000) e Bhattacharya, Lovell e Sahay (1997) assinalam que os bancos estrangeiros são mais eficientes do que os bancos domésticos nos países em desenvolvimento. Nessa mesma linha de raciocínio, Demirguc-Kunt e Huizinga (2000) defendem que a lucratividade dos bancos estrangeiros é superior à dos bancos domésticos em países em desenvolvimento, ocorrendo o inverso no caso dos países desenvolvidos. A resposta para esses resultados é que o quadro macroeconômico e institucional é diferente para países desenvolvidos e em desenvolvimento.

Conquanto exista essa disparidade na eficiência dos bancos estrangeiros dependendo das características do país destinatário, o aumento do PIB é um resultado comum para os países que recebem esse tipo de influxo de capital (Demirguc-Kunt, Levine e Min, 1998; Grahan, 2004; Levine, 1999).

Todavia, há riscos de longo prazo com a entrada desses bancos, como o receio de que empresas de pequeno e médio porte fiquem sendo atendidas pelos bancos domésticos enquanto as grandes empresas contem com o suporte dos bancos estrangeiros. Entretanto, medidas reguladoras podem sanar esse empecilho, como a determinação do governo de que determinado percentual do crédito de um banco financie empresas específicas, o que poderia minar essa disparidade.

\subsection{Entrada e Restrições}

Os bancos estrangeiros podem entrar em novos países com o intuito de simplesmente seguirem os seus clientes. Nesse caso, multinacionais corriqueiramente são o tipo de cliente que recebem esse suporte dos bancos através de financiamentos e produtos financeiros. Cabe ressaltar que esse tipo de entrada não representa uma rivalidade no mercado bancário para os bancos domésticos, dado que o objetivo precípuo dos bancos estrangeiros é a manutenção e 
apoio de velhos clientes. Entretanto, essa entrada pode representar maior eficiência para o país receptor, uma vez que o crescimento da empresa multinacional pode representar aumento no emprego, variedade de produtos ofertados e melhores salários, não obstante o fato de que a incursão de bancos estrangeiros pode carregar benefícios ao sistema financeiro do país, como ressaltado nas subseções anteriores.

Outro tipo de entrada é por meio da fusão e aquisição de bancos domésticos, na qual a propriedade doméstica passa a ser controlada por estrangeiros, portanto, esse tipo de IDE não criaria novas instituições físicas no mercado local. Essa entrada apresenta alguns riscos como a prática de transfer pricing, que é caracterizada pela transferência de dívidas no ato de adquirir outra propriedade e a redução de empréstimos para pequenas empresas, como de fato se observou em alguns países em desenvolvimento (Chang e Grabel, 2004; Clarke et al, 2003). Por outro lado, o investimento direto estrangeiro na forma de greenfield pode trazer benefícios para a nação receptora, quais sejam, aumento do emprego, do crédito e da eficiência do mercado bancário (Clarke et al, 2003; De Young, Goldberg e White, 1999; Goldberg e White, 1998).

Saindo do tema sobre a entrada desses bancos e seguindo para as restrições que essas instituições enfrentam, segue que de acordo com alguns estudos que serão citados se pode depreender que, de forma análoga ao raciocínio elaborado sobre a entrada de bancos, maiores generalizações dos efeitos de restrições devem ser feitas com cautela, dada a variedade dos resultados observados, entretanto, a literatura tem convergido para o apoio à redução de fortes barreiras, embora regulações e limitadas restrições sejam defendidas concomitantemente.

Restringir o acesso dos bancos estrangeiros ao uso dos fundos públicos acarreta a redução dos seus empréstimos para o mercado doméstico, segundo Pomerleano e Vojta (2004). Esse fato representa uma vantagem comparativa para os bancos domésticos e não permite que os novos entrantes exerçam suas economias de escala e auxiliem o país a aumentar o escopo do mercado bancário. Ademais, esse tipo de restrição exacerba o caráter pró-cíclico típico de economias em desenvolvimento (Epstein e Grabel, 2007).

Mais traços prejudiciais que podem emergir com a restrição tanto da entrada como na atuação dos bancos estrangeiros são: aumento da fragilidade do setor bancário, redução da eficiência dos bancos estrangeiros, aumento dos custos operacionais do sistema como um todo e limitados spillovers (Barth, Caprio e Levine, 2004; Hao, Hunter e Yang, 2001). No estudo de Hao, Hunter e Yang (2001) é citado a Coreia como exemplo de país que limitou a ação dos bancos estrangeiros e, por isso, recebeu irrisórios ganhos de eficiência no setor bancário. 
Deste modo, uma análise rigorosa deve ser realizada para medir os custos e benefícios da entrada dos bancos estrangeiros, bem como possíveis restrições impostas a eles, e assim mitigar possíveis efeitos deletérios que podem surgir.

\subsection{Bancos Estrangeiros}

Os bancos estrangeiros são caracterizados por possuírem uma plataforma global de funcionamento, isto é, são agentes que aprofundam o fenômeno da globalização financeira e colocam o país receptor em maior contato com outras nações. Gerenciam fundos de capitais globais, o que permite que realizem diversas tarefas de difícil manuseio pelos bancos domésticos como operações de câmbio, derivativos, empréstimos transfronteiriços e gestão de caixa com múltiplas moedas. É um novo canal pelo qual o capital estrangeiro pode adentrar no país, bem como novas técnicas e serviços financeiros, propiciando maior liquidez na economia, o que por sua vez pode incrementar o dinamismo da atividade produtiva ao permitir o florescimento de diversos empreendimentos que careciam do suporte de uma instituição mais moderna e eficiente. Em especial, muitos desses bancos são peritos em fusões e aquisições e o contato deles com os bancos domésticos pode ocasionar o aprendizado dessa perícia por esses bancos, tornando o objetivo de se internacionalizarem menos hercúleo ou ajudando-os a se protegerem de possíveis aquisições estrangeiras hostis.

O maior nível de habilidade e experiência dos trabalhadores dos bancos estrangeiros representa um acréscimo no nível do capital humano do país receptor. Ademais, a remuneração desses empregos ocorre primordialmente com base no mérito pelos objetivos atingidos e em geral os salários são mais altos para tarefas que exigem maior competência. Deste modo, a entrada desses bancos pode acarretar maior nível de emprego e de salários. Programas para o aperfeiçoamento da mão de obra através de treinamentos também ocorrem, como o fazem o Citibank e o J. P. Morgan (Pomerleano e Vojta, 2004).

Esses bancos trazem consigo novos contatos estrangeiros; são contatos que podem futuramente render acordos com os agentes domésticos, como novos canais de exportação. $\mathrm{O}$ contato dos bancos entrantes com a cultura local pode influenciar no curso das instituições domésticas no sentido defendido por North (1989; 1990). Países em que as mulheres sofrem preconceitos para obterem um lugar no mercado de trabalho podem perceber uma reversão nesse quadro na medida em que os bancos estrangeiros, como dito anteriormente, trabalham com base na meritocracia, sem distinção de gênero, portanto, a produtividade de cada trabalhador é o que importaria para a sua contratação. Conforme essa característica se 
aprofundasse, ela poderia alterar o paradigma social do país, no caso explicitado, a desigualdade social entre os sexos e, assim, as instituições vigentes.

A crise financeira de 2008-2009 pode ter representado um novo marco para os bancos estrangeiros, pois estes não fugiram do país quando ela eclodiu (Claessens e Van Horen, 2014). Essa é uma possibilidade amplamente questionada, se com uma crise local o banco estrangeiro ficaria ou sairia. Prospectos de lucros futuros podem ter ajudado nessa decisão pelos bancos, em detrimento das perdas que certamente ocorreriam no curto prazo, deste modo, objetivos de longo prazo se sobrepuseram sobre os de curto prazo.

Alianças com os bancos domésticos podem ocorrer, pois se um tem melhores técnicas de funcionamento, o outro possui maior conhecimento local, e essa união certamente fortalece ambas as partes. Nesse mérito, reformas domésticas podem ser aceleradas, uma vez que a união entre os bancos cria uma convergência no tocante a possíveis melhoramentos no sistema bancário doméstico (Levine, 1996; Pomerleano e Vojta, 2004).

A prática de too big to fail, que é caracterizada pela tentativa dos bancos aumentarem os seus tamanhos e importância no sistema financeiro de modo a serem considerados grandes o bastante para falirem, foi um dos motivos para o irromper da crise de 2008-2009 nos EUA (Dymski, 2009; Dymski, 2012). Essa política distorce o mercado financeiro, pois instituições que passam a ser consideradas too big to fail recebem melhor avaliação e, assim, se tornam mais bem valorizadas, sendo que não necessariamente realizam atividades produtivos, mas tão somente operações financeiras. Ademais, empresas que são realmente produtivas recebem menor valoração do mercado, deturpando o lado real da economia.

Goldberg (2009) denota que bancos estrangeiros realizam pouca transferência de tecnologia e de produtividade para o sistema bancário doméstico. É concebível pensar dessa maneira, uma vez que o gap tecnológico entre países desenvolvidos e em desenvolvimento não se resolve simplesmente por transferindo instituições mais modernas para mercados mais atrasados, desconsiderando toda a dinâmica do aprendizado e absorção da tecnologia. Aliado a isso, a distância cultural entre os países é outro fator que prejudica os ganhos de eficiência do mercado doméstico, bem como os ganhos produtivos para os bancos estrangeiros.

O governo pode melhorar o funcionamento do sistema bancário e, por conseguinte, aumentar a probabilidade de que os bancos estrangeiros transfiram suas técnicas para os bancos domésticos. Goldberg (2009) observa que os governos passaram a serem exigidos em buscar uma maior disciplina macroeconômica para que o país se tornasse atrativo para o influxo de capital externo. Inflação controlada, crescimento sustentado do PIB e ajustamento das contas 
internas e externas são meios pelos quais os Estados podem atingir credibilidade internacional e melhorar o ambiente bancário.

Entre as vantagens e desvantagens dos bancos estrangeiros, percebe-se que o governo pode ter um importante papel em reduzir possíveis efeitos indesejáveis e propiciar um melhor funcionamento do sistema bancário, que ao auxiliar atividades produtivas e permitir maior acesso de pessoas de baixa renda em produtos financeiros que propiciam compras de bens que permitam desfrutar de um melhor padrão de vida, o bem estar é incrementado, além de acelerar o desenvolvimento econômico.

\subsection{Crédito}

Essa é a última subseção dessa seção que analisa as consequências da entrada dos bancos estrangeiros. O comportamento do crédito no país que recebe as instituições estrangeiras pareceu obscuro de se entender nos anos de 1990, entretanto, atualmente a literatura tem defendido a relação de bancos estrangeiros com a melhora no crédito, principalmente quando se leva em conta as características do país destinatário.

As pequenas e médias empresas foram analisadas por Clarke, Cull e Peria (2001) e os autores denotaram que as empresas maiores se beneficiaram mais do crédito, contudo, empresas menores vislumbraram maiores oportunidades de lucros no futuro. $\mathrm{O}$ aumento da eficiência que os bancos entrantes normalmente acarretam ajuda a entender esse horizonte de longo prazo promissor para empresas de tamanho menor, sem negligenciar outros possíveis efeitos benéficos para a economia que podem surgir - aos quais foram explanados em outras subseções - e auxiliar no melhor desempenho dessas firmas.

De Haas e Van Lelyveld (2014) asseveram que após a crise financeira de 2008-2009 os bancos estrangeiros reduziram em maior volume os seus empréstimos em comparação aos bancos domésticos, todavia, Claessens e Van Horen (2013) assinalam que esse comportamento do crédito somente ocorreu em países nos quais os bancos estrangeiros não possuíam um papel proeminente no sistema bancário, pois nos países em que esses bancos tinham funções vitais para o sistema financeiro o crédito não decresceu. Mathieson e Roldós (2004) narram que na crise asiática os empréstimos transfronteiriços e locais efetuados pelos bancos estrangeiros experimentaram uma contração durante a crise, o que aprofundou o grau da crise econômica. Por outro lado, Dages, Goldberg e Kinney (2000) ao analisarem a crise mexicana de 1994-1995 denotam que não é a propriedade do banco que importa para compreender o comportamento do crédito, mas tão somente a sua saúde financeira. $\mathrm{O}$ denominar comum desses estudos é de que 
não há um comportamento padrão dos bancos estrangeiros durante crises, porém, compreender o funcionamento dessas instituições, as características do país local e a relação entre o sistema bancário doméstico e os bancos estrangeiros são peças fundamentais para prever o comportamento destes durante crises.

A entrada desses bancos pode desencadear a inclusão de pessoas outrora excluídas do sistema financeiro, bem como aumentar a eficiência alocativa do crédito na medida em que suas condicionalidades para ser liberado se adequem às condições da população atendida (Detragiache, Tressel e Gupta, 2008). Essa lacuna no mercado bancário é uma característica de muitos países em desenvolvimento e a falta de liquidez em determinadas partes desses países paralisa atividades econômicas de caráter frágil ou mesmo inviabiliza o surgimento delas. Preencher essas partes ausentes do sistema bancário é um passo fundamental para a superação de mazelas sociais como a pobreza. Entretanto, transparência e regulação devem acompanhar todo o processo, vide a crise das hipotecas subprime dos EUA em 2008, em que empréstimos predatórios, isto é, créditos com altas taxas de juros e fortes colaterais, foram concedidos para segmentos mais pobres da população.

Gormley (2010) chama a atenção para o risco da prática denominada de "cherry pick". Ao entrar em um novo país, alguns bancos estrangeiros costumam tomar os melhores clientes dos bancos domésticos. No longo prazo, essa situação pode causar o enfraquecimento dos bancos domésticos, dado que passaram a ficar com os clientes menos rentáveis; aumento da taxa de inadimplência no mercado bancário; a tomada de maiores riscos pelos bancos prejudicados, de forma a voltarem a terem o rendimento anterior; e, portanto, o crédito da economia é prejudicado. Novamente, maior regulação e transparência devem ser estabelecidos para minar esse tipo de problema.

Esses estudos ajudam a perceber os benefícios que os bancos estrangeiros podem gerar, tornando o crédito mais estável, incluindo pessoas de baixa renda, barateando-o através da queda da margem da taxa de juros e avanços tecnológicos e funcionando como uma fonte de estabilidade para o país em crises financeiras. A despeito dos riscos que podem surgir com a entrada das instituições estrangeiras, transparência e regulação devem ser intrínsecos ao processo, não deixando de mencionar uma estratégia que envolva o horizonte temporal de longo prazo para conseguir deixar o sistema bancário mais eficiente, demorando a retirar as restrições caso os bancos domésticos necessitem de um tempo de ajuste, por exemplo.

\section{CONCLUSÃO}


Ao longo do artigo foi traçada a tendência de maior incursão dos bancos estrangeiros, principalmente em países em desenvolvimento, desde os anos de 1990. Ainda que muitas incertezas sobre as consequências da entrada dos bancos estrangeiros persistam, os estudos dirigidos a essa questão têm reduzido essas dúvidas, embora algumas ainda permaneçam. Ademais, os efeitos benéficos advindos desse influxo têm incentivado várias nações a reduzirem suas restrições para essas instituições.

Entretanto, questionamentos se é realmente prudente deixar o setor bancário doméstico sendo controlado majoritariamente por bancos estrangeiros são realizados, bem como debates sobre efeitos ainda não muito bem claros desses bancos. Portanto, e como foi recomendado durante o trabalho, a entrada desses bancos deve vir acompanhada previamente por transparência, regulação e um estudo sobre o funcionamento da instituição entrante e as características do país receptor, de modo a conseguir endereçar as necessidades e objetivos locais com o banco estrangeiro. Além de considerar que "cada caso é um caso", ou seja, o que funcionou para determinado país pode não engrenar em outro, o que, novamente, exige um estudo da economia em questão.

Problemas sociais como a fome, pobreza e desigualdade de renda são questões que precisam de resolução e não podem ser adiadas, portanto, a entrada dos bancos estrangeiros deve ser efetuada para incrementar o desenvolvimento econômico e social do país receptor. $\mathrm{E}$ a integração regional que vem ocorrendo mundialmente e que tem sido fortalecida pelos bancos estrangeiros pode ser outro traço que ajude a fortalecer o funcionamento desses bancos, criando uma maior cooperação entre agentes nacionais e internacionais.

\section{REFERÊNCIAS}

BARTH, J. R., CAPRIO, G. e LEVINE, R. Bank Regulation and Supervision: What Works Best? Journal of Financial Intermediation, v. 13, n. 2, p. 205-248, 2004.

BERGER, A. N. et al. Globalization of Financial Institutions: Evidence from Cross-Border Banking Performance. Brookings Papers on Financial Services, v. 3, 2000.

BHATTACHARYA, A., LOVELL, C. A. e SAHAY, P. The Impact of Liberalization on the Productive Efficiency of Indian Commercial Banks. European Journal of Operational Research, v. 98, n. 2, p. 332-345, 1997.

CETORELli, N. e GAMBERA, M. Banking Market Structure, Financial Dependence and Growth: International Evidence from Industry Data. The Journal of Finance, v. 56, n. 2, p. 617-648, 2001. 
CHANG, C. E. et al. Efficiency of Multinational Banks: An Empirical Investigation. Applied Financial Economics, v. 8, n. 6, p. 1-8, 1998.

CHANG, H. J. e GRABEL, I. Reclaiming Development: An Alternative Economic Policy Manual. London: Zed Books, 2004.

CLAESSENS, S. e VAN HOREN, N. Impact of Foreign Banks. Journal of Financial Perspectives, v. 1, n. 1, p. 29-42, 2013.

; VAN HOREN, N. Foreign Banks: Impact and Trends. Journal of Money, Credit and Banking, v. 46, n. 1, p. 295-326, 2014.

CLARKE, G.; et al. Foreign Bank Entry: Experience, Implications for Developing Economies, and Agenda for Further Research. The World Bank Research Observer, v. 18, n. 1, p. 25-59, 2003.

CLARKE, G. ; CULL, R. e PERIA, M. S. M. Does Foreign Bank Penetration Reduce Access to Credit in Developing Countries? Evidence from Asking Borrowers. The World Bank, n. 2716, 2001.

DAGES, G., GOLDBERG, L. S. e KINNEY, D. Foreign and Domestic Bank Participation in Emerging Markets: Lessons from Argentina and Mexico. FRBNY Economic Policy Review, 2000.

DE HAAS, R. e VAN LELYVELD, I. Multinational Banks and The Global Financial Crisis: Weathering the Perfect Storm. Journal of Money, Credit and Banking, v. 46, n. 1, suplemento, p. 333-364, 2014.

DE YOUNG, R. e NOLLE, D. E. Foreign-Owned Banks in the United States: Earning Market Share or Buying It? Journal of Money, Credit, and Banking, v. 28, n. 4, p. 622-636, 1996.

DE YOUNG, R; GOLDBERG, L. G. e WHITE, L. J. Youth, Adolescence, and Maturity of Banks: Credit Availability to Small Business in an Era of Banking Consolidation. Journal of Banking and Finance, v. 23, n. 2, p. 463-492, 1999.

DEMIRGUC-KUNT, A; HUIZINGA, H. Determinants of Commercial Bank Interest Margins and Profitability: Some International Evidence. Word Bank Economic Review, v. 13, n. 2, p. 379-408, 2000.

DEMIRGUC-KUNT, A; LEVINE, R. e MIN, H. G. Foreign Banks: Efficiency, Stability and Growth. In: LEE, S. (ed.) The Implications of Globalization of World Financial Markets. Seoul: Bank of Korea, 1998.

DETRAGIACHE, E. e GUPTA, P. Foreign Banks in Emerging Market Crises: Evidence from Malaysia. Journal of Financial Stability, v. 2, n. 3, p. 217-242, 2006. 
DETRAGIACHE, E.; TRESSEL, T. e GUPTA, P. Foreign Banks in Poor Countries: Theory and Evidence. The Journal of Finance, v. 63, n. 5, p. 2123-2160, 2008.

DYMSKI, G. A. Financial Risk and Governance in the Neoliberal Era. In: CLARK, G. L, DIXON, A. D. e MONK, A. H. (ed.) Managing Financial Risks: From Global to Local. Oxford University Press, p. 48-68, 2009.

O Gênio Fora da Garrafa: A Evolução da Política Too Big to Fail e a Estratégia Bancária dos Estados Unidos. In: CINTRA, M. e GOMES, K. (eds.) As Transformações no Sistema Financeiro Internacional. Brasília: Instituto de Pesquisa Econômica Aplicada (IPEA), p. 177-244, 2012.

EPSTEIN, G. e GRABEL, I. Financial Policies for Pro-Poor Growth: A Training Manual. Prepared for the United Nations Development Programme (UNDP). International Poverty Centre. Global Training Programme on Economic Policies for Growth, Employment and Poverty Reduction, 2007.

FRY, M. Money, Interest, and Banking in Economic Development. Baltimore: Johns Hopkins University Press, 1988.

GOLDBERG, L. G. e WHITE, L. J. De Novo Banks and Lending to Small Businesses: An Empirical Analysis. Journal of Banking and Finance, v. 22, n. 6, p. 851-867, 1998.

GOLDBERG, L. S. Understanding Banking Sector Globalization. IMF Staff Papers, v. 56, n. 1, p. 171-197, 2009.

GORMLEY, T. A. The Impact of Foreign Bank Entry in Emerging Markets: Evidence from India. Journal of Financial Intermediation, v. 19, n. 1, p. 26-51, 2010.

GRAHAN, E. M. Opening Banking to Foreign Competition. In: LITAN, R. E., MASSON, P. e POMERLEANO, M. (eds.) Open Doors: Foreign Participation in Financial Systems in Developing Countries. Brookings Institutions Press, 2004.

HAO, J., HUNTER, W. C. e YANG, W. K. Deregulation and Efficiency: The Case of Private Korean Banks. Journal of Economics and Business, v. 53, n. 2, p. 237-254, 2001.

KIRALY, J. et al. Experience with Internationalization of Financial Service Providers - Case Study: Hungary. In: CLAESSENS, S. e JANSEN, M. (eds.) The Internationalization of Financial Services: Issues and Lessons for Developing Countries. Boston: Kluwer Academic, 2000.

LAPAVITSAS, C. Financialised Capitalism: Crisis and Financial Expropriation. Historical Materialism, vol. 17, p. 114-148, 2009. 
Theorizing Financialization. Work, Employment and Society, vol. 25, n. 4, p. 611626, 2011.

LEVINE, R. Foreign Banks, Financial Development, and Economic Growth. In: BARFIELD, C. E. (ed.) International Financial Markets: Harmonization versus Competition. Washington: The AEI Press, 1996.

Law, Finance, and Economic Growth. Journal of Financial Intermediation, v. 8, n.

1, p. 8-35, 1999.

. Bank Concentration: Chile and International Comparisons. Working Paper, $\mathrm{n}^{\circ} 62$.

Santiago: Central Bank of Chile, 2000.

MATHIESON, D. J. e ROLDÓS, J. Foreign Banks in Emerging Markets. In: LITAN, R. E., MASSON, P. e POMERLEANO, M. (eds.) Open Doors: Foreign Participation in Financial Systems in Developing Countries. Brookings Institutions Press, 2004.

MCKINNON, R. Money and Capital in Economic Development. Brookings Institution, 1973.

MISHKIN, F. S. Why We Shouldn't Turn our Backs on Financial Globalization. IMF Staff Papers, v. 56, n. 1, p. 139, 2009.

NORTH, D. Institutions and Economic Growth: An Historical Introduction. World Development, v. 17, n. 9, p. 1319-1332, 1989.

Institutions, Institutional Change and Economic Performance. Cambridge: Cambridge University Press, 1990.

POMERLEANO, M. e VOJTA, G. J. Foreign Banks in Emerging Markets: An Institutional Study. In: LITAN, R. E., MASSON, P. e POMERLEANO, M. (eds.) Open Doors: Foreign Participation in Financial Systems in Developing Countries. Brookings Institutions Press, 2004.

SHAW, E. S. Financial Deepening in Economic Development. New York: Oxford University, 1973.

WILLIAMSON, J. e MAHAR, M. A Survey of Financial Liberalization. Essays in International Finance, n. 211. Princeton, New Jersey: International Finance Section, Economics Department, Princeton University, 1998. 